\title{
The Influence of Host-Country's Environments on the FDI Entry Mode Choice of Chinese Companies
}

\author{
Song-Hua Hu \\ Lingnan College, Sun Yat-sen University, China \\ E-mail: lnshsh@mail.sysu.edu.cn \\ Hai-Yan Ma \\ Lingnan College, Sun Yat-sen University, China \\ E-mail: apple3085@126.com \\ Guang-Tao Zen \\ Lingnan College, Sun Yat-sen University, China \\ E-mail: bellona_green@hotmail.com \\ Accepted: April 12, 2012 \\ Online Published: June 8, 2012 \\ URL: http://dx.doi.org/10.5430/bmr.v1n2p39
}

Received: March 16, 2012

doi:10.5430/bmr.v1n2p39

This research is funded by China's Ministry of Education under Grant No. $10 Y J A 630064$

\begin{abstract}
Based on a sample of 280 China's listed companies with foreign direct investment (FDI) during 2005-2009, this paper examines how the country-specific factors influence these firms' FDI entry mode choice between mergers and acquisitions (M\&As) and greenfield investment. Our results show that in the presence of higher country risk or more rapid economic growth, the Chinese enterprises prefer the greenfield investment. When the host country has stronger national innovation ability or a higher level of human capital, the enterprises tend to choose the entry mode of cross-border M\&As. An increase in the cultural distance, excluding the effect of other variables, appears to induce the enterprises to select M\&A entry mode. However, when factor endowments and other institutional environments are taken into consideration, the cultural distance produces no significant effect on FDI entry mode choice of these Chinese firms.
\end{abstract}

Keywords: Location Advantages, FDI, Entry Mode Choice, Chinese Firms, Internationalization

\section{Introduction}

In recent years, the rapid growth of China's outward FDI has been phenomenal. Despite the world's financial crisis, China's non-financial FDI increased from USD40.6 billion in year 2008 to USD59 billion in year 2010, recording the growth rate of 45.3\% (MOFCOM, 2011). Although Chinese firms are still at an early stage of internationalization, China has become the top FDI exporter among developing countries.

According to Dunning's eclectic paradigm, location advantages, in addition to the firm's ownership advantages and internalization advantages, are important determinants of the FDI entry mode choice (Dunning 2001). A large number of empirical studies have been made to investigate the role of location-specific factors in shaping FDI entry strategies, including the host country's economic size, economic growth, country risk, cultural distance, national innovation ability and knowledge systems (Alvarez \& Marin,2009;Barkemaden \& Vermeulen,1998; Brouthers \& Brouthers,2002; Pak \& Park, 2004; Slangen \& Hennart, 2008). However, much of the literature is concentrated on the FDI activities of the multinational enterprises (MNEs) from developed countries. The research on emerging market (EM) MNEs has been focused on the motivations and driving forces behind their international expansion (Baharumshah and Almasaied, 2009: Buckley et al., 2007; Demirbag, Tatoglu \& Glaister, 2009; Rui \& Yip, 2008). There is insufficient empirical evidence about the influence of location factors on the FDI entry mode choice of EM MNEs in general, and Chinese firms in particular (Xu, Hu \& Fan, 2011; Cui and Jiang, 2010). 
FDI entry strategies of EM enterprises deserve more research not only because of their increasing numbers and their recently rapid foreign expansion, but more importantly, because of their distinct characteristics. EM firms appear to take different internationalization paths from that of Western counterparts. First, unlike the MNEs from developed countries, EM enterprises use FDIs as a springboard to remedy their competitive disadvantages, rather than to exploit their competitive advantages abroad (Child \& Rodrigue, 2005; Deng, 2004; Luo, 2007). Second, Western MNEs place strategic emphasis on transferability of their ownership advantages, and generally look for host countries with natural resources, cheap labor, and markets with sufficient absorptive capacity. In contrast, EM firms with strategic intent to procure competitive assets like to select the FDI locations that provide strategic access to advanced technologies, reputable brands and information (Peng \& Wang, 2000). Third, Western MNEs are uneasy with sharing resources in partnerships with indigenous firms. EM MNEs see the benefits of tapping into the resources of partnerships, and their internationalization is driven by resource linkage, leverage and learning (Mathews, 2006).

While sharing the similarities with other EM firms, Chinese MNEs also demonstrate their unique national features in their FDI activities. When acquiring foreign assets, Chinese firms adopt a more aggressive approach as compared to others (Cui \& Jiang, 2008). As for the geographical locations, U.S., Netherlands, Canada and Australia are among the top 10 destinations of China's outward FDI (MOFCOM, 2010). In certain host countries, many Chinese MNEs face FDI entry barriers because of their state-ownership. It has been exemplified by the restrictive measures imposed on Chinese FDI by the US governments (Globerman \& Shapiro, 2009). Given the rich content of Chinese firms' internationalization, the study on their FDI entry strategies has strong implications for international business theory. This paper attempts to investigate the impact of host countries' environments on the FDI entry mode choice between M \& As and greenfield investment by Chinese firms. Using the dataset from a sample of 280 listed companies in China's stock exchanges, we make the logistic regression analysis, and our results prove to be fruitful.

The locational factors in this study are classified into two types: the institutional environments and factor endowments. The first type includes country risk, economic growth and cultural distance between the host country and China. The second refers to the host country's national innovation ability and its level of human capital. The basic analytic framework for this study is described in Figure 1.

The rest of this paper is structured as follows: Section 2 reviews the literature on the relationship between location factors and FDI mode choice to formulate testable hypotheses. Section 3 discusses variable selections, empirical design, the sample and descriptive statistics. In section 4, the empirical results are presented and analyzed. Section 5 summarizes the findings and the implications.

\section{Hypotheses Development}

\subsection{The Relationship between Country Risk and FDI Mode Choice}

Country risk refers to the possibility of an economic loss due to the change of political, legal, economic and other environmental factors in the host country. Since an increase in country risk indicates greater uncertainty of the host country's environment, there is more likelihood of losses for the investing firms and thus a higher risk premium is required for the entry into the market. In recent years, more and more state-owned or state-controlled Chinese firms have made FDI. One primary reason is that the Chinese government's policies toward FDI have shifted from tight control to active encouragements. Since the host country's government is often concerned with the political motive of foreign investors, Chinese firms tend to face high political risks when making FDI in the form of the cross-border M\&As (Globerman \& Shapiro, 2009). In fact, a number of Chinese firms' cross-border M\&A attempts ended up in failure because the host countries objected on the grounds of national security and economic security. Furthermore, a high country risk tends to reduce the financing availability of the capital market for foreign investors. Cross-border M\&As rely on the capital markets more than greenfield investments. Once the capital market failure occurs, the foreign firms may fall into the trouble in which they cannot strip the redundant assets or have access to complementary assets (Demirbag, 2008). In comparison, if the greenfield mode is selected, the foreign firms are subject to lower country risk as the host country's government often considers such a form of FDI as a way of increasing the local employment. Based on the discussion above, we propose the following hypothesis:

H1: As the host country risk increases, the enterprises prefer the greenfield entry mode.

\subsection{Economic Growth and FDI Mode Choice}

Economic growth rate reflects the changes in an economy' performance during a period of time. It is a basic indicator of economic vitality. The higher a country's economic growth rate is, the less saturated the market becomes. Greenfield investment is a suitable mode under such a condition as the investing firm can expand profitably with the growing market. Conversely, if a host country's economic growth rate is low, the market tends to be saturated, and 
competition will intensify. Since greenfield investment takes a long process, this entry mode makes it difficult for the foreign firms to establish the competitive position quickly. In such a saturated market, cross-border M\&As would be preferred because it's likely for the acquiring firms to obtain the strategic assets at low prices, and quickly capture the market share of the acquired firms (Larimo, 2003). Although such conjectures concerning the impact of economic growth on FDI entry choice have been supported by a number of empirical studies, there are still controversies. In the view of Caves and Mehra (1986), no entry or slow entry into a growing market will cause the firms to miss great investment opportunities. Given such huge opportunity costs, cross-border M\&As will be a more effective entry mode than greenfield investment. Another argument is that the relationship between the host country's economic growth and FDI mode choice is U-shaped (Hennart \& Park, 1993).

Currently, the overall competitiveness of Chinese enterprises cannot match that of the Western counterparts, but outmatch that of most developing countries. When making FDI in developed countries with slower economic growth, Chinese firms are motivated to remedy competitive disadvantages by acquiring strategic capabilities. When making FDI in developing countries with rapid economic growth, Chinese firms prefer greenfield investment in order to leverage their competitive advantages, and exploit long-term opportunities in growing markets. Therefore, it is appropriate to test the following hypothesis:

H2: the faster the host country's economic growth is, the more likely the Chinese firms will choose the entry mode of greenfield investment.

\subsection{Cultural Distance and FDI Mode Choice}

Cultural distance denotes the differences in the shared value system between two countries $(\mathrm{Hu}, 2006)$. A large cultural distance represents a big obstacle which often hinders the firm's exploitation of its capabilities in the foreign market. The foreign firms will be in a disadvantageous position to compete against local companies as it is difficult for the foreign firms to manage the relations with the local employees, customers, suppliers and governments in a foreign market. Entry by acquisition will reduce such a foreignness problem. The foreign firm can open up the local market quickly with the help of the acquired local company that not only understands the host country's environments, but also has the established business networks (Brouthers, 2000). Conversely, when the cultural difference is small, greenfield investment is a suitable entry mode because it can prevent the occurrence of opportunistic behavior and reduce the dissemination risk (Agarwal, 1994). However, Barkema and Vermeulen (1998) show that the firms are likely to select greenfield investments in the presence of a large cultural distance so as to prevent the technology from leaking out and exploit effectively the firm's ownership advantages. But such an argument rests on the assumption that the MNEs have strong technological advantages and rich international experience, and their strategic focus is placed on the full exploitation of their ownership advantages. This may not be applicable to the China context because Chinese firms, still on the early stages of internationalization, have adopted a dual strategy to explore competitive advantages in developed countries and to exploit competitive advantages in emerging economies. Thus we propose the third hypothesis.

H3:A larger cultural distance is associated with a higher propensity of the firms to choose entry by cross-border M\&As.

\subsection{National Innovation Capability, Human Capital Level and FDI Mode Choice}

National innovation capacity is a country' ability to continuously introduce new technologies over a long period of time. The country with strong innovation ability has not only a high stock of knowledge, but also more advanced production system and technology system (Alvarez \& Marin, 2009). MNEs from emerging economies like China tend to treat FDI as a springboard to acquire strategic resources, so that they can overcome their latecomer disadvantages (Luo \& Tung, 2007). Then, entry by acquisition is an effective means for these firms to quickly obtain complementary assets. By using the acquired company's technical and commercial basis, the acquiring firms can enjoy both "spillover effect" and the "demonstration effect" in technology. Meanwhile, the relatively matured institutional environment in the host country is also conducive for the firms to upgrade technology and production capabilities. The study of Alvarez and Marin (2009) shows that the strong national innovation capacity has a significant impact on the firms' FDI decision to choose cross-border M\&As.

National human capital represents a country's abilities of workforce to create economic value. The quality of human capital can be improved through training and experiential learning. In a country with a higher level of human capital, labor costs are generally higher. Since greenfield investment involves the establishment of a new entity abroad, it's necessary to recruit a large number of local employees in the host country, and as a result, the increased foreign operation costs may not warrant this type of FDI mode. Under such a situation, cross-border M\&As are preferred 
because the investing firms can acquire the strategic assets like technology and high quality factors of production available in the host country. On the other hand, if the host country has a low level of national human capital, its labor will be cheaper. Lower cost of production may be the main motive for FDI in such a country. The investing firms can get huge savings from labor costs through greenfield investments than entry by M\&As (Demirbag, 2008). According to the empirical study of Antaloczy and Sass (2001), when labor-intensive production moves to low labor cost locations, the firms tend to choose greenfield investments.

Based on the discussion above, the following hypotheses can be tested:

H4: The stronger the innovative capability of the host country is, the more likely the firms will choose the entry by M\&As.

H5: The higher the level of the host country's human capital is, the more likely the enterprises will choose the M\&A entry mode.

\section{Empirical Design}

\subsection{Source of Sample}

For this study, a sample of China's listed companies with foreign operations are selected randomly from the OSIRIS databank. The data include the amount of firms' intangible assets, the number of overseas subsidiaries, the host countries of FDI, the shares held by the parent companies in overseas subsidiaries during the years of 2005-2009. We searched for the information about FDI entry mode choices of these companies from the Internet (www.baidu.com). After excluding the firms with incomplete data, we have a sample of 280 firms. FDI entry modes are defined as an ordinal variable with two values: " 1 " for cross-border M\&As and "0" for greenfield investments.

\subsection{Variables and Measurement}

As shown in Table 3-1, there are five independent variables in total. The data for country risk, CR, is obtained from the national risk assessment report released by Euromoney in September 2009. To make the data convenient for our analysis, we take the inverse of all the scores, and thus, a larger value represents a higher country risk. Economic growth, GDPG, measures the average annual growth rate of the host country's GDP during the years of 2005-2009, available on IMF website. Culture distance, $\mathrm{CD}$, is measured in terms of four cultural dimensions index updated by Hofstede (2005). It is calculated as follows:

$$
C D_{j}=\sum_{i=1}^{4} \frac{\left(I_{i j}-I_{i c}\right)^{2} / V_{i}}{4}
$$

where $I_{i j}$ is the distance index for the $i^{\text {th }}$ cultural dimension and $j^{\text {th }}$ country, $V_{i}$ is the variance of the index of $i^{\text {th }}$ culture dimension, $c$ stands for China, and $C D_{j}$ represents the cultural distance between country $j$ and China. The host country's innovation capability, NIC, is measured by the ratio of the country's R \& D investment to GDP (Alvarez et al., 2009). Its data is obtained from the World Bank's World Development Indicators database (WDI). A higher value of NIC indicates stronger national innovation ability. The level of host country's human capital, HCL, is measured by the population attending high school as a percentage of the total working-age population. The data is also obtained from the WDI. A larger value of HCL stands for a higher level of the national human capital.

In this study, the firms' international experience is treated as a controlled variable. It's gauged by the total number of overseas subsidiaries which can be viewed as proxy for ownership advantages. Tacit knowledge (TK) represents the firm's internalization advantages, measured by the total amount of the firm's intangible assets. Corporate ownership structure, OWS, reflects the control degrees of parent companies over the overseas subsidiaries. Given its influence on the FDI mode choice, it's also controlled here. If the MNE owns over $95 \%$ of the shares of the foreign subsidiaries, it's a full ownership, and OWS has a value of 1 . If the shareholding is between $10 \%$ to $95 \%$, it is a partial ownership, and OWS has a value of 0.

\subsection{Descriptive Statistics}

As Table 3-2 shows, in our sample of 280 observations, 172 companies selected green investment, accounting for $61.43 \%$ of the total; 108 firms chose cross-border M\&As, accounting for $38.57 \%$. In terms of ownership structure, 192 firms established the wholly owned subsidiaries, accounting for $68.57 \%$ of the total, and 88 firms set up joint-venture, accounting for $31.43 \%$.

\subsection{The Model}

Since the dependent variable is an unordered categorical variable, we employ binomial logistic regression for the 
analysis. Our basic model is:

$$
P\left(Y_{i}=1\right)=\frac{1}{1+\exp \left(-\alpha-X_{i} \beta\right)}
$$

where $\mathrm{P}(\mathrm{Yi}=1)$ is the estimated probability of the ith observation value with cross-border M\&As, and Xi represents the matrix of independent variables and control variables that have influences on the ith observation's FDI mode choice. $\alpha$ is constant matrix and $\beta$ is regression coefficient matrix. When the regression coefficient is positive, it indicates that the firms prefer FDI entry by cross-border M\&As. The following seven models are formulated for binomial logistic regressions:

Model 1:Mode $=\alpha_{0}+\alpha_{1}$ OWS $+\alpha_{2}$ IEXP $+\alpha_{3}$ TK

Model 2:Mode $=\alpha_{0}+\alpha_{1} \mathrm{CR}+\alpha_{2} \mathrm{OWS}+\alpha_{3} \mathrm{IEXP}+\alpha_{4} \mathrm{TK}$

Model 3:Mode $=\alpha_{0}+\alpha_{1}$ GDPG $+\alpha_{2}$ OWS $+\alpha_{3}$ IEXP $+\alpha_{4}$ TK

Model 4:Mode $=\alpha_{0}+\alpha_{1}$ CD $+\alpha_{2}$ OWS $+\alpha_{3}$ IEXP $+\alpha_{4}$ TK

Model 5:Mode $=\alpha_{0}+\alpha_{1}$ NIC $+\alpha_{2}$ OWS $+\alpha_{3}$ IEXP $+\alpha_{4}$ TK

Model 6:Mode $=\alpha_{0}+\alpha_{1}$ HCL $+\alpha_{2}$ OWS $+\alpha_{3}$ IEXP $+\alpha_{4}$ TK

Model 7:Mode $=\alpha_{0}+\alpha_{1} \mathrm{CR}+\alpha_{2}$ GDPG $+\alpha_{3} \mathrm{CD}+\alpha_{4} \mathrm{NIC}+\alpha_{5} \mathrm{HCL}+\alpha_{6} \mathrm{OWS}+\alpha_{7} \mathrm{IEXP}+\alpha_{8} \mathrm{TK}$

\section{Empirical Results}

Table 4-1 is asymptotic correlation matrix of the main variables. It can be seen that the correlation between the main variables are not so high to be concerned with multicoleararity problem.

Table 4-2 shows that the pseudo-coefficients of the determinants in the seven models are quite satisfactory. It indicates that these regression models can explain the dependent variables and variations well. In addition, the Chi-square value in the seven models' likelihood ratio test results is relatively larger, and the comprehensive tests of the seven models are also significant on the level of 0.001 . So it can be concluded that the degree of fitting for these regression equations is good. Finally, based on Hosmer and Lemeshow Test, we can see that all the models are significant in the level of 0.05 or 0.01 .

Table 4-3 is the parameter estimation of each model based on binomial logistic regression. In all regression models, coefficients of all variables, except cultural distance, are significant at the level of 0.05 or 0.1 . It suggests that the location advantages have a significant impact on FDI entry mode choice. In model 2 and 7, country risk is negative and significant at the level of 0.01 , indicating that a higher country risk is associated with the firms' higher propensity to choose the entry mode of greenfield investment. In the model 3 and 7, the coefficients for economic growth are both negative and significant at the level of 0.01, implying that a higher economic growth rate of the host country tends to induce the firms to choose greenfield investment. In model 5 and 7, the coefficients for national innovation capabilities are both negative and significant at the level of 0.01 , lending support to hypothesis 4 that stronger national innovation capacities increases the likelihood to adopt the entry mode of cross-border M\&As. In model 6 and 7, the coefficients of the national human capital level are both negative and significant at the level of 0.01 or 0.1 , confirming hypothesis 5 that a higher level of the national human capital is correlated with the firms' preference of an acquisitive entry.

The coefficient of the culture distance is positive and significant at the 0.01 of level in model 4 while it is negative and not significant in model 7. Thus, we can only conclude that excluding the impact of other location factors, a larger cultural distance increases the likelihood of the firms to select entry by cross-border M\&As. When the companies take full account of the impact of other country-specific factors, the cultural distance plays a weak role in FDI entry mode choice. A possible reason is that this study has not incorporated the effects of time and the firms' market experience with the host country. As Chang and Rosenzweig (2001) point out, when the firm first enters a country with large culture differences, it would choose greenfield investments in order to avoid cultural conflict. With increased familiarity with the host country's social and cultural environment, the firm would tend to choose M\&As.

Regarding control variables, the coefficients of international experience in the seven models are all positive and significant at the level of 0.05 or 0.01 . The result implies that more international experiences increase the firms' preference of the acquisitive entry. The coefficients of corporate ownership structure are positive and significant at the level of 0.01 in all the models. It means that Chinese companies that decide to set up joint ventures are more likely to choose cross-border M\&As than the ones with the intention to have a full ownership in the subsidiaries. 
This may result from the policy restrictions of local governments on the shares held by the foreign firms in the local companies.

\section{Conclusion}

As Chinese firms are accelerating the pace of internationalization, they play an increasingly important role in world markets, and there is an increasing need for the study of their FDI entry modes. Using a sample of Chinese companies listed on the stock exchanges in Shanghai, Shenzhen and Hong-Kong, this paper examines the role of location advantages in their mode choices between greenfields and M\&As. The results show that both higher country risk and more rapid economic growth induce the firms to choose greenfield investment. Strong national innovation ability, and higher level of national human capital, are associated with the firms' preference of acquisitive entries. The firms are more likely to enter culturally distant countries through M\&As if the effect of other location variables are excluded. However, when more location-specific factors are taken into consideration, the cultural distance produces no significant effect on FDI entry mode choice of these Chinese firms. The decision on joint ventures vs. wholly owned subsidiaries also influences the choice between greenfield and acquisitive entries. These results reveal how the host countries' environmental determinants shape FDI entry strategies of Chinese firms.

Although this study has produced insightful results, it's limited to a moderate sample of China's listed companies from a databank. Further research based on first-hand data like questionnaires may be necessary to shed more light on the issue. Furthermore, the relationship between location advantages and FDI entry mode choice is influenced by a number of ownership and internalization factors. An expanded study can be undertaken by incorporating more control variables such as the technological capabilities and the marketing capabilities of Chinese enterprises. It can help us understand better the impact of locational factors on FDI entry mode choices of EM enterprises in the context of other firm-specific variables.

\section{References}

Agarwal, S. (1994). Socio-cultural distance and the choice of joint ventures: a contingency perspective. Journal of International Market, 2:2, 63-80.

Alvarez, I.. \& Marin R. (2009). FDI entry modes and the relevance of host country differences. GLOBELICS 2009, 7th International Conference. Georgia Institute of Technology, 1-39.

Antaloczy, K. \& Sass M. (2001). Greenfield investments in Hungary: Are they different from privatization FDI? Transnational Corporations, 39-59.

Baharumshah, A. Z. \& Almasaied S. W. (2009). Foreign direct investment and economic growth in Malaysia: Interactions with human capital and financial deepening, Emerging Markets Finance and Trade, 45:1, 91-102. http://dx.doi.org/10.2753/REE1540-496X450106

Barkema, H.G. \& Vermeulen F. (1998). International expansion through start-up or acquisition: a learning perspective. Strategic Management Journal, 41:1, 7-26.

Brouthers, K.D. \& Brouthers L.E. (2000). Acquisition or greenfield start-up? Institutional, cultural and transaction $\begin{array}{lllll}\text { cost influences. Strategic Management } & \text { Journal, } & \text { 21:1, } & \text { 89-97. }\end{array}$ http://dx.doi.org/10.1002/(SICI)1097-0266(200001)21:1<89::AID-SMJ85>3.0.CO;2-8

Brouthers, K.D., Brouthers, L.E. \& S. Werner (2002). Industrial sector, perceived environmental uncertainty and entry mode strategy. Journal of Business Research, 55:3, 495-507. http://dx.doi.org/10.1016/S0148-2963(00)00154-5

Buckley, P. J., Clegg L. J., Cross A. R., Liu X., Voss H. \& Zheng P. (2007). The determinants of Chinese outward foreign direct investment. Journal of International Business Studies, 38:2, 499-518. http://dx.doi.org/10.1057/palgrave.jibs. 8400277

Caves, R.E. \& Mehra S.K. (1986). Entry of foreign multinationals into U.S. manufacturing industries. Chapter in Competition global industries, Michael Porter(ed), Boston: Harvard Business Sehool, 547-689.

Chang, S.-J. \& Rosenzweig, P. M. (2001). The Choice of Entry Mode in Sequential Foreign Direct Investment. Strategic Management Journal, 22:8, 747-776. http://dx.doi.org/10.1002/smj.168

Chen, S.-F. (2008). The motives for international acquisitions: capability procurements, strategic considerations, and the role of ownership structures. Journal of International Business Studies, 39, 454-471. http://dx.doi.org/10.1057/palgrave.jibs.8400357

Cui, L. \& Jiang F. (2009). FDI entry mode choice of Chinese firms: A strategic behavior perspective. Journal of World Business, 44:4, 434-444. http://dx.doi.org/10.1016/j.jwb.2008.11.004 
Demirbag, M., Tatoglu E. \& Glaister K.W. (2008). Factors affecting perceptions of the choice between acquisition and greenfield entry: The case of Western FDI in an emerging market. Management International Review, 48:1, 5-30. http://dx.doi.org/10.1007/s11575-008-0002-3

Demirbag, M.,Tatoglu E. \& Glaister K.W. (2009). Equity-based entry modes of emerging country multinationals: Lesson from Turkey. Journal of World Business, 44: 4, 445-462. http://dx.doi.org/10.1016/j.jwb.2008.11.009

Dunning, J.H. (2001). The eclectic (OLI) paradigm on international production: Past, present and future, International Journal of Economics \& Business, 8:2, 170-190. http://dx.doi.org/10.1080/13571510110051441

Globerman, S. \& Shapiro D. (2009). Economic and strategic considerations surrounding Chinese FDI in the United States. Asia Pacific Journal of Management, 26:1,163-183. http://dx.doi.org/10.1007/s10490-008-9112-5

Hofstede, G. Cultures and organizations: Software of the mind (2nd ed.). New York: McGraw-Hill., 2005.

Hu, S. H. (2006). International Business Management, Sun Yat-sen University Press.

Larimo, J. (2003). Form of investment by Nordic firms in world markets. Journal of Business Research, 56:10, 791-803. http://dx.doi.org/10.1016/S0148-2963(02)00467-8

Luo, Y.D. \& Tung, R. L. (2007). International expansion of emerging market enterprises: A springboard perspective. Journal of International Business Studies, 38:4, 481-499. http://dx.doi.org/10.1057/palgrave.jibs.8400275

MOFCOM (2010). Statistical Bulletin of China's Outward Foreign Direct Investment, http://hzs.mofcom.gov.cn

Pak, Y.S. \& Park, Y.R. (2004). Global Ownership Strategy of Japanese Multinational Enterprises: A Test of Internalization Theory. Management International Review, 44:1, 3-21.

Slangen, A. H. \& Hennart, J.F. (2008). Do multinationals really prefer to enter culturally distant countries through greenfields rather than through acquisitions? The role of parent experience and subsidiary autonomy. Journal of Business Research, 39:3, 472-491.

Xu, Y.H., Hu, S.H., \& Fan, X.A. (2011). Entry mode choice of Chinese enterprises: The impacts of country risk, cultural distance and their interactions. Frontier of Business Research in China, 5:1, 63-78. http://dx.doi.org/10.1007/s11782-011-0121-8

Table 3-1 Variable Selection and Measurement

\begin{tabular}{|c|c|c|c|}
\hline $\begin{array}{l}\text { Dependent } \\
\text { Variable }\end{array}$ & FDI Mode(MODE) & $\begin{array}{l}\text { 0-Greenfield(GF) } \\
\text { 1-M\&A(MA) }\end{array}$ & $\begin{array}{c}\text { Padmanabhan \& } \\
\text { Cho,1999;Larimo,2003 }\end{array}$ \\
\hline \multirow{5}{*}{$\begin{array}{l}\text { Independent } \\
\text { Variable }\end{array}$} & Country risk(CR) & $\begin{array}{c}\text { Political \& legal risk of } \\
\text { host countries }\end{array}$ & $\begin{array}{l}\text { Demirbag, et al.,2008 } \\
\text { Xu, et al., } 2011\end{array}$ \\
\hline & $\begin{array}{l}\text { Economic growth } \\
\text { rate(GDPG) }\end{array}$ & $\begin{array}{l}\text { GDP growth rate of host } \\
\text { countries }\end{array}$ & $\begin{array}{c}\text { Caves \& Mehra, 1986; } \\
\text { Hennart \& Park,1993 }\end{array}$ \\
\hline & Cultural distance(CD) & $\begin{array}{l}\text { Cultural differences } \\
\text { between China \& host } \\
\text { country }\end{array}$ & $\begin{array}{l}\text { Kogut\&Singh,1988; } \\
\text { Xu, et al., } 2011\end{array}$ \\
\hline & $\begin{array}{l}\text { National innovation } \\
\text { ability(NIC) }\end{array}$ & $\begin{array}{l}\text { R\&D as a percentage of } \\
\text { the host country's GDP }\end{array}$ & Alvarez \& Marin,2009 \\
\hline & $\begin{array}{c}\text { National level of human } \\
\text { capital(HCL) }\end{array}$ & $\begin{array}{l}\text { High school students / total } \\
\text { working population }\end{array}$ & Alvarez \& Marin,2009 \\
\hline \multirow{3}{*}{$\begin{array}{l}\text { Control } \\
\text { variable }\end{array}$} & $\begin{array}{c}\text { Ownership } \\
\text { structure(OWS) }\end{array}$ & $\begin{array}{c}\text { 0-Wholly owned } \\
\text { subsidiary(WOS), } \\
\text { 1-Joint venture(JV) }\end{array}$ & $\begin{array}{c}\text { Larimo,2003; } \\
\text { Chen S.-F.,2008 }\end{array}$ \\
\hline & Tacit knowledge(TK) & $\begin{array}{l}\text { Amount of the firm's } \\
\text { tangible assets }\end{array}$ & $\begin{array}{l}\text { Brouthers \& Brouther, } \\
2002\end{array}$ \\
\hline & $\begin{array}{c}\text { International } \\
\text { experience(IEXP) }\end{array}$ & $\begin{array}{l}\text { Total number of the firm's } \\
\text { overseas subsidiaries }\end{array}$ & Claver \& Quer,2005 \\
\hline
\end{tabular}


Table 3-2 Descriptive Statistics of the Sample

\begin{tabular}{c|c|c|c}
\hline \multicolumn{2}{|c|}{} & Observations & Percentage \\
\hline $\begin{array}{c}\text { FDI } \\
\text { Mode(MO } \\
\text { DE) }\end{array}$ & Greenfield(0) & 172 & $61.43 \%$ \\
\cline { 2 - 4 } & Cross-border M\&A(1) & 108 & $38.57 \%$ \\
\hline $\begin{array}{c}\text { Ownership } \\
\text { Structure } \\
\text { (OWS) }\end{array}$ & $\begin{array}{c}\text { Wholly-owned } \\
\text { subsidiaries(0) }\end{array}$ & 192 & $68.57 \%$ \\
\cline { 2 - 4 } & Joint venture(1) & 88 & $31.43 \%$ \\
\hline \multicolumn{2}{c}{ Valid observations } & 280 & $100.0 \%$ \\
\hline \multicolumn{2}{c}{ Invalid observations } & 0 & \\
\hline \multicolumn{2}{c}{ Total observations } & 280 & \\
\hline
\end{tabular}

Table 4-1 the Asymptotic Correlation Matrix of the Main Variables

\begin{tabular}{c|c|c|c|c|c|c|c|c}
\hline & 1. OWS & 2. IEXP & 3.TK & 4 . CR & 5.GDPG & 6. CD & 7.NIC & 8. HCL \\
\hline 1.OWX & 1 & & & & & & & \\
\hline 2.IEXP & -0.241 & 1 & & & & & & \\
\hline 3. TK & -0.111 & 0.114 & 1 & & & & & \\
\hline 4.CR & -0.071 & 0.002 & -0.090 & 1 & & & & \\
\hline 5.GDPG & -0.140 & 0.129 & -0.039 & 0.477 & 1 & & & \\
\hline 6. CD & 0.131 & -0.186 & -0.041 & 0.142 & -0.501 & 1 & & \\
\hline 7. NIC & 0.173 & -0.154 & 0.040 & -0.344 & -0.509 & 0.477 & 1 & \\
\hline 8. HCL & 0.132 & -0.095 & 0.173 & -0.464 & -0.456 & 0.469 & 0.547 & 1 \\
\hline
\end{tabular}

Table 4-2 Models' Likelihood Ratio Test and the Coefficients of Determination

\begin{tabular}{c|c|c|c|c|c|c|c|c}
\hline \multicolumn{2}{c|}{ Model } & $\mathbf{1}$ & $\mathbf{2}$ & $\mathbf{3}$ & $\mathbf{4}$ & $\mathbf{5}$ & $\mathbf{6}$ & $\mathbf{7}$ \\
\hline \multicolumn{2}{c|}{ Cox \& Snell R-square } & 0.147 & 0.277 & 0.322 & 0.249 & 0.364 & 0.286 & 0.476 \\
\hline Nagelkerke R-square & 0.200 & 0.376 & 0.437 & 0.338 & 0.495 & 0.388 & 0.646 \\
\hline -2 Log Likelihood & 328.799 & 282.507 & 264.747 & 293.380 & 246.602 & 279.081 & 192.526 \\
\hline Omnibus & Chi-Squar & 44.604 & 90.897 & 108.657 & 80.023 & 126.802 & 94.323 & 180.877 \\
Test of & df & 3 & 4 & 4 & 4 & 4 & 4 & 8 \\
Model & Sig. & 0.000 & 0.000 & 0.000 & 0.000 & 0.000 & 0.000 & 0.000 \\
Coefficients & & & & & & \\
\hline Hosmer and & Chi-Squar & 19.557 & 21.386 & 16.922 & 16.940 & 18.885 & 17.461 & 15.811 \\
Lemeshow & df & 8 & 8 & 8 & 8 & 8 & 8 & 8 \\
Test & Sig. & 0.012 & 0.006 & 0.031 & 0.031 & 0.015 & 0.026 & 0.045 \\
\hline
\end{tabular}


Table 4-3 Binomial Logistic Regression Results

\begin{tabular}{|c|c|c|c|c|c|c|c|}
\hline Model & 1 & 2 & 3 & 4 & 5 & 6 & 7 \\
\hline $\begin{array}{c}\text { INTER } \\
\text { CEPT }\end{array}$ & $\begin{array}{c}-5.152 * * * \\
(1.166) \\
\end{array}$ & $\begin{array}{c}3.339 \\
(2.062) \\
\end{array}$ & $\begin{array}{c}-4.601 * * * \\
(1.346) \\
\end{array}$ & $\begin{array}{c}-7.414 * * * \\
(1.412) \\
\end{array}$ & $\begin{array}{c}-9.838 * * * \\
(1.683) \\
\end{array}$ & $\begin{array}{c}-9.887 * * * \\
(1.580) \\
\end{array}$ & $\begin{array}{c}2.800 \\
(4.541)\end{array}$ \\
\hline CR & & $\begin{array}{c}-7.259 * * * \\
(1.525) \\
\end{array}$ & & & & & $\begin{array}{c}-11.235^{* * *} \\
(3.623) \\
\end{array}$ \\
\hline GDPG & & & $\begin{array}{c}-0.692 * * * \\
(0.105) \\
\end{array}$ & & & & $\begin{array}{c}-0.802 * * * \\
(0.216) \\
\end{array}$ \\
\hline CD & & & & $\begin{array}{c}0.551 * * * \\
(0.100)\end{array}$ & & & $\begin{array}{l}-0.357 \\
(0.288) \\
\end{array}$ \\
\hline NIC & & & & & $\begin{array}{c}1.731 * * * \\
(0.233) \\
\end{array}$ & & $\begin{array}{c}1.334 * * * \\
(0.024) \\
\end{array}$ \\
\hline HCL & & & & & & $\begin{array}{c}0.058 * * * \\
(0.010)\end{array}$ & $\begin{array}{l}0.029 * \\
(0.015) \\
\end{array}$ \\
\hline OWS & $\begin{array}{c}1.640 * * * \\
(0.304)\end{array}$ & $\begin{array}{c}1.909 * * * \\
(0.343)\end{array}$ & $\begin{array}{c}1.844 * * * \\
(0.355)\end{array}$ & $\begin{array}{c}1.702 * * * \\
(0.328)\end{array}$ & $\begin{array}{c}1.918^{* * *} \\
(0.380)\end{array}$ & $\begin{array}{c}1.672 * * * \\
(0.334)\end{array}$ & $\begin{array}{c}2.630 * * * \\
(0.475) \\
\end{array}$ \\
\hline IEXP & $\begin{array}{c}0.019 * * * \\
(0.006)\end{array}$ & $\begin{array}{c}0.024 * * * \\
(0.007)\end{array}$ & $\begin{array}{c}0.032 * * * \\
(0.007)\end{array}$ & $\begin{array}{c}0.029 * * * \\
(0.007)\end{array}$ & $\begin{array}{c}0.038^{* * *} \\
(0.008)\end{array}$ & $\begin{array}{c}0.027 * * \\
(0.007)\end{array}$ & $\begin{array}{c}0.053 * * * \\
(0.010)\end{array}$ \\
\hline TH & $\begin{array}{c}0.287 * * * \\
(0.084)\end{array}$ & $\begin{array}{c}0.306^{* * *} \\
(0.089)\end{array}$ & $\begin{array}{c}0.361 * * * \\
(0.099)\end{array}$ & $\begin{array}{c}0.351 * * * \\
(0.096)\end{array}$ & $\begin{array}{c}0.382 * * * \\
(0.105)\end{array}$ & $\begin{array}{c}0.215^{* * *} \\
(0.092)\end{array}$ & $\begin{array}{c}0.441 * * * \\
(0.122)\end{array}$ \\
\hline
\end{tabular}

Note: the value inside () is the standard errors of parameter estimates, * indicates that the coefficient is significant at the level of 0.10 (wald test), ** indicates that the coefficient is significant at the level of 0.05 (wald test), *** means the coefficient is significant at the level of 0.01 (wald test).

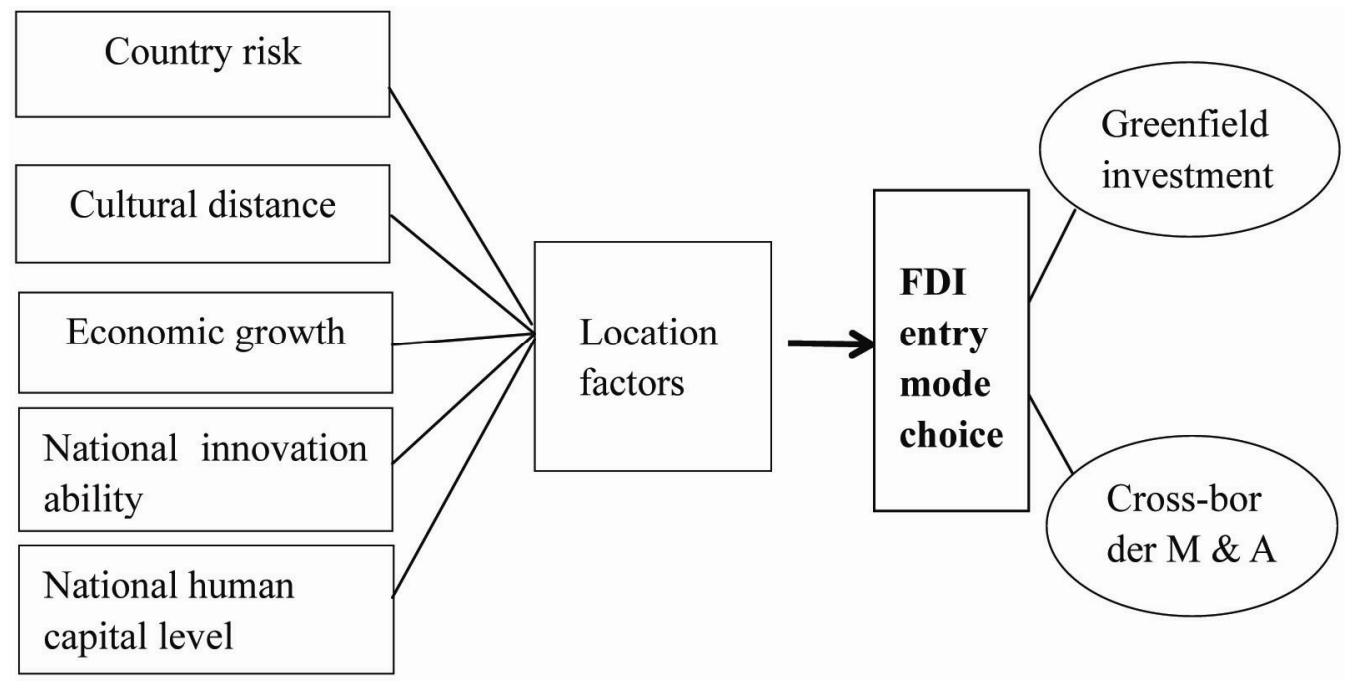

Figure 1. Analytic Framework 